\title{
The Appeal of Cartoon Characters in Instructional Media through Animation in Early Childhood Education in Surakarta
}

\author{
B H Prilosadoso \\ Faculty of Art and Design, Institut Seni Indonesia (ISI) Surakarta, Indonesia \\ Corresponding author email: basnendart@yahoo.com

\section{R A Kurniawan} \\ Faculty of Art and Design, Institut Seni Indonesia (ISI) Surakarta, Indonesia \\ Email: rendyakurniawan@gmail.com

\section{B Pandanwangi} \\ Faculty of Art and Design, Institut Seni Indonesia (ISI) Surakarta, Indonesia \\ Email: brilindra@gmail.com \\ I K Yunianto \\ Faculty of Art and Design, Institut Seni Indonesia (ISI) Surakarta, Indonesia \\ Email: ipungkacamata@gmail.com
}

\begin{abstract}
Animated learning media using cartoon characters is an appropriate means of supporting learning methods in Early Childhood Education in the Surakarta area, Central Java, Indonesia. This research method includes data collection, data analysis, and presentation of data analysis. This research method uses a qualitative descriptive approach through data sources that include learning materials, animated cartoon characters, literature study through the stages of analysis obtained from various sources of information in interactive references. The investigation stages from multiple sources of information, both literature reviews and interviews, were carried out using an interactive model, where each research component includes the steps of data collection, data reduction, presentation, and conclusion drawing. The use of cartoon characters in animation learning media is beneficial for students who are very interesting and able to receive material and participate in learning activities. Also, animated audiovisual media are needed by students and teachers by using cartoon characters in it.
\end{abstract}

Keywords---animation, cartoon characters, early childhood education, learning media.

\section{Introduction}

The rapid development of information technology in the current era is a challenge for Indonesians who still uphold their ancestral culture, where conditions by the increasingly intense Western culture domination through various information technology advance. The existence of digital technology media changes the way we view and think about ourselves and the universe (Darmawan, 2016). At this time, care and concern, especially early childhood, to the ancestors' arts and cultural heritage are increasingly marginalized compared to western culture, which is very interesting and varied. The existence of local culture today is considered critical because of its massive influence due to modern culture (Prilosadoso et al., 2020).

Human life that begins in the womb of the mother is then born and develops into adulthood. The stages in each age are related to each other as a whole in one unit. The development process of each child begins with reflexes and then the development of the central nervous system and other functions, such as motor, emotional, intellectual, and social aspects (Putri et al., 2019). They were learning material for children through educational content through 
various games, storytelling, playing, and other activities carried out correctly. According to their age, helping children develop to get to know their environment (Fikraturrosyida, 2018).

This research approach focuses on children in primary school and kindergarten education in the Surakarta area, Central Java, Indonesia. The research object for Early Childhood Education by all educational efforts to facilitate children's development from birth to six years of age by providing various experiences and stimuli that are developing, integrated, and comprehensive can grow and develop comprehensively positive. Healthy and optimal following the morals and life adopted (Sutedjo, Prilosadoso, 2016).

The role of technology and communication, where one of them is by the emergence of learning to students using graphic design, is the animation media that is starting to be used in elementary and preschool education today. Advances in technology and information have enabled a combination of coordination and coordination of verbal presentation modes with various narratives and text on display with nonverbal presentation techniques in the form of graphic design, video, animation, and sound in one device in the form of computers, gadgets and other audiovisual devices (Moreno \& Mayer, 1999; Lee \& Magnenat-Thalmann, 2000). Optical media in the form of animation is the most suitable means of assisting learning methods in early childhood. This study will describe the importance of learning media in the form of animation, which has advantages in all aspects, both visually, soundly, material, and messages that students can receive in the learning process.

The development of animation today is not only targeting children but also adolescents and adults. Animated media is crucial in learning media in elementary schools and kindergartens today, where at their age, the ability to absorb audiovisual media is very quickly accepted by them. The benefits of animation related to education will be more exciting and useful in today's education world (Rosmiati et al., 2020). Animation media is a visualization technique widely used in the world of education today, both as a whole, as part of live-action, and as an integral part of live-action. The film world has its roots in photography, while animation stems from visual elements, namely illustration, and graphic design. Of the teachers who participated in the study, teachers and students spent most of their time watching cartoons, whereas as a result, many cartoon characters influenced students who tried to do what they did; the undeniable impact of cartoon characters on students (Turan, 2014; Höffler \& Leutner, 2007). Cartoons are one of the most-watched programs by children on television. Cartoons, which are entertainment tools, are widely available in various media today (Gökçearslan, 2010). Therefore, alternative media are needed to develop learning media for early childhood. Animation-based learning media can be accepted and of course, attractive. Based on the introduction above, this research will be developed to develop animation as a medium of information, education, and is useful for increasing understanding of educational and recreational materials in early childhood.

\section{Materials and Methods}

This audiovisual applied research will design animated instructional media through cartoon characters for early childhood education in Surakarta, Central Java, Indonesia which aims to provide alternative learning media with a qualitative descriptive research approach to maximize the research objectives. A qualitative research approach like this can trace back to the explanation by McLean \& Campbell (2003), that in the researcher's activities it is left to his apparatus in the task of weighing the consequences that will be caused by one or more sampling methods in research, knowing that sampling is an inseparable unity. Part of a series. research, which can undoubtedly "make or break" analysis (Noy, 2008; Ogle et al., 2017).

The method in this research was developed by formulating the principles in the animation literature (Kwon \& Lee, 2011). This fine arts research is a primary data content source and several cartoon character designs for animated learning media for early childhood education. It can explain the stages of designing an expository animation work regarding animated illustrations with cartoon characters through the process's steps, a). Choose a name; b). Choose a background; c). Add dialogue, and d). Live. (Xiao, 2013; Grelotti et al., 2005).

Test the validity of the data in this study of animation learning media through cartoon characters using data triangulation which consists of three aspects: triangulation of data sources and triangulation of theories. Data triangulation is a step in checking the validity of the data by comparing it with other elements. The data analysis technique took several stages: data collection, data reduction, data presentation, and concluding. 
Results and Discussions

Character cartoon as aspect main to learning media animation

The benefits of animation technology related to learning media are exciting and useful in today's education world. Where almost all user experiences, both teachers and students, have used and seen simple animation media in several simple applications and other software that have been widely circulating in the community. Besides, individual schools and educational institutions have even used animation software that is more complex and complicated to use alternative learning media (Mayer, 2003; Gikas \& Grant, 2013). The notion of cartoons which are representational or symbolic images contains elements of satire, jokes, or humor. Cartoons usually appear periodically that raise issues from politics, social, economy, and everyday life (Prilosadoso, 2007). Whereas in previous research, it has shown that cartoon images help attract and motivate students in learning, and help improve mastery of learning materials (Deepaen, 2016). According to Anderson (1990) that in its delivery, cartoons use indirect language, in this way, different from the language used in news, speeches, and gossip denotatively (Sunarto, 2012).

Technological developments in the last decade, where rapid computing capacity and the advancement of visual communication design technology, multimedia learning media have changed and evolved from static and monotonous text to increasingly sophisticated and attractive media. Two distinctive aspects seem to be popular among designers and other practitioners. The use of animation media has an impact on students' ability to interact with educational material (Betrancourt, 2005).

Therefore, to become a more exciting and interactive learning media for early childhood education in schools, the media is needed to provide education and recreation elements. Can obtain media by designing animated media with cartoon characters that still adjust to the intended segmentation: social, economic, geography, age, audience, and learning material aspects. It takes appropriate media and communication in delivering material, especially learning media related to tools that carry messages between communicators or publishers and communicants or user communities. To be able to evaluate the effectiveness of various communication media, several dimensions are needed (Prilosadoso et. al., 2019). Teachers or education practitioners can categorize animated content as learning media through cartoon characters in the classroom into three types, namely: a). Expositive: students can see directly from the monitor screen; b). Interactive: students can learn interactively, and c). Quiz: students can find out how good they are in receiving learning material through an easy test (Xiao, 2013).

\section{Conclusion}

The research results are conclusions about cartoon characters' application in learning animation in early childhood, as follows. Cartoon characters without obstacles in teaching media in animation can support student acceptance in teaching materials. In the following conclusions: Early Childhood Education Students are very interested in cartoon characters in learning, namely the influence of essential cartoon characters. Besides, teachers or educators with visual and audio effects are needed for students and use cartoon characters in education and can design educational and nature programs that are very liked by early childhood.

\section{Acknowledgments}

At the end of writing a scientific article, the entire drafting team is very grateful to all those who have supported this compilation process from the beginning to the final stage of writing this scientific article. The writing team would also like to thank the Indonesian Institute of the Arts (ISI) Surakarta and many other parties who have helped until completing this article.

\section{References}

Anderson, B. R. O. G. (1990). Language and power: Exploring political cultures in Indonesia. Cornell University Press.

Bétrancourt, M. (2005). The animation and interactivity principles in multimedia learning. The Cambridge handbook of multimedia learning, 287-296.

Darmawan, F. (2016). Modalitas Visual Kartunis dalam Kartun Politik Online Pascareformasi.

Deepaen, W. (2016). Global Journal of Foreign Language Teaching. Language Teaching, 6(2), 104-110.

Fikraturrosyida, V. (2018). Perancangan Ambient Media Sebagai Sarana Promosi Permainan Tradisional Komunitas Anak Bawang Surakarta (Doctoral dissertation, FAKULTAS SENI RUPA DAN DESAIN). 
Gikas, J., \& Grant, M. M. (2013). Mobile computing devices in higher education: Student perspectives on learning with cellphones, smartphones \& social media. The Internet and Higher Education, 19, 18-26. https://doi.org/10.1016/j.iheduc.2013.06.002

Gökçearslan, A. (2010). The effect of cartoon movies on children's gender development. Procedia-social and behavioral sciences, 2(2), 5202-5207. https://doi.org/10.1016/j.sbspro.2010.03.846

Grelotti, D. J., Klin, A. J., Gauthier, I., Skudlarski, P., Cohen, D. J., Gore, J. C., ... \& Schultz, R. T. (2005). fMRI activation of the fusiform gyrus and amygdala to cartoon characters but not to faces in a boy with autism. Neuropsychologia, 43(3), 373-385. https://doi.org/10.1016/.j.neuropsychologia.2004.06.015

Höffler, T. N., \& Leutner, D. (2007). Instructional animation versus static pictures: A meta-analysis. Learning and instruction, 17(6), 722-738. https://doi.org/10.1016/j.learninstruc.2007.09.013

Kwon, J. Y., \& Lee, I. K. (2011, July). Cartoon-like stylization for character animation. In 2011 International Symposium on Ubiquitous Virtual Reality (pp. 48-51). IEEE.

Lee, W. S., \& Magnenat-Thalmann, N. (2000). Fast head modeling for animation. Image and Vision Computing, 18(4), 355-364. https://doi.org/10.1016/S0262-8856(99)00057-8

Mayer, R. E. (2003). The promise of multimedia learning: using the same instructional design methods across different media. Learning and instruction, 13(2), 125-139. https://doi.org/10.1016/S0959-4752(02)00016-6

McLean, C. A., \& Campbell, C. M. (2003). Locating research informants in a multi-ethnic community: ethnic identities, social networks and recruitment methods. Ethnicity and health, 8(1), 41-61.

Moreno, R., \& Mayer, R. E. (1999). Cognitive principles of multimedia learning: The role of modality and contiguity. Journal of educational psychology, 91(2), 358.

Noy, C. (2008). Sampling knowledge: The hermeneutics of snowball sampling in qualitative research. International Journal of social research methodology, 11(4), 327-344.

Ogle, A. D., Graham, D. J., Lucas-Thompson, R. G., \& Roberto, C. A. (2017). Influence of cartoon media characters on children's attention to and preference for food and beverage products. Journal of the Academy of Nutrition and Dietetics, 117(2), 265-270. https://doi.org/10.1016/j.jand.2016.08.012

Prilosadoso, B. H. (2007). Bias Gender Dalam Kartun Editorial Di Media Cetak. Jurnal Ornamen, 4(2), 61-71.

Prilosadoso, B. H., Pujiono, B., \& Supeni, S. (2020). The Character of the Pacitan Wayang Beber Cartoon as a Cultural Preservation Effortfor Millennial's Generation. International Journal of Advanced Science and Technology, 29(4), 2517-2522. http://sersc.org/journals/index.php/IJAST/article/view/21090

Prilosadoso, B. H., Pujiono, B., Supeni, S., \& Setyawan, B. W. (2019). Wayang beber animation media as an effort for preserving wayang tradition based on information and technology. In Journal of Physics: Conference Series (Vol. 1339, No. 1, p. 012109). IOP Publishing.

Putri, R. O. C. E., Firdausi, N. A., Susetya, B. A., \& Prilosadoso, B. H. (2019). Pelestarian Cerita Ramayana Melalui Media Wayang Limbah Kertas Untuk Siswa Sekolah Dasar Di Sukoharjo. Prosiding: Seni, Teknologi, Dan Masyarakat, 2, 245-251.

Rosmiati, A., Kurniawan, R. A., Prilosadoso, B. H., \& Panindias, A. N. (2020). Aspects of Visual Communication Design in Animated Learning Media for Early Childhood and Kindergarten. International Journal of Social Sciences, 3(1), 122-126.

Sunarto, P. (2012). Editorial Cartoon Visual Metaphor in Jakarta Newspapers at 1950-1957. TAWARIKH, 3(2).

Sutedjo, A., \& Prilosadoso, B. H. (2016). Perancangan Desain Permainan Materi Pendidikan Anak Usia Dini Berbasis Wayang Beber. Acintya Jurnal Penelitian Seni Budaya, 8(1).

Turan, B. (2014). The opinions of teachers on the use of cartoon character in the mathematics lesson. Procedia-Social and Behavioral Sciences, 141, 1386-1391. https://doi.org/10.1016/j.sbspro.2014.05.239

Xiao, L. (2013). Animation trends in education. International Journal of Information and Education Technology, 3(3), 286. 